DOI 10.18551/rjoas.2021-07.28

\title{
TRADITIONAL MEDIA AS A MEANS OF SUBMITTING PUBLIC INFORMATION FOR INDIGENOUS COMMUNITIES IN AMBON ISLAND
}

\author{
Rumra Fatmawati \\ Faculty of Social and Political Sciences, Pattimura University, Indonesia \\ E-mail: idenlesta@gmail.com
}

\begin{abstract}
The community still uses traditional media to deliver information to the people of the Old Hitu Hitu Country. This research uses a qualitative approach with a case study method. This research was carried out in this research located in the Old Hitu Country, Leihitu District, Central Maluku Regency. The study results show that the traditional communication used by the people of the Old Hitu Country in disseminating public information through the representation of the customary council. The use of traditional media in communication in disseminating Public Information in the Hitu Country is carried out by using traditional media to convey information related to the Indigenous government and the State Government itself. Traditional communication has advantages for indigenous peoples because it builds harmony between the King of Hitu and the people. The accessibility of traditional media in delivering public information through traditional media in Hitu is still being carried out and maintained by the King, such as Sansiri and Tifa.
\end{abstract}

\section{KEY WORDS}

Traditional media, public information, public service.

Indonesia has various tribes and customs still preserved by traditional leaders in a particular region or area. According to Suprawoto (2011), Indonesia is an archipelagic country consisting of 17,508 islands, 485 ethnic groups, and 583 regional languages. This fact shows the diversity of ethnicities, languages, customs, communication patterns, and local cultures that exist in each of these ethnic groups. Indonesia is very rich with various traditional media or folk performance media to convey information or to entertain. The variety of traditional media used to convey messages, ideas, or opinions in Indonesia is very large (Alkhajar, 2018). According to Blake and Haralson (Cangara, 2002), media is a medium used to convey a message, where this medium is a path or tool with a message running between the communicator and the communicant. In the past, we can know that before all these technologies were discovered, humans had communicated with various types of traditional media in conveying various information needed by the community through mediums such as myths, folklore, expressions or proverbs, arts in the form of songs, dances, paintings, work literature, sculpture, traditional cloth, rituals, and so on.

Communication policy cannot be separated from national policy; even communication policy is an integrated part of other development policies. Communication can contribute to supporting the implementation of national development programs in each country. According to Hafied Cangara (2013), communication policy as a resource is as important as other sectors in nation-building; even national policies built on sectoral policies cannot be separated from communication policies and planning. Communication must be given an equal position in determining a country's policies (Cangara, 2013). Communication has a strong potential in carrying out social change efforts, especially in encouraging the acceleration of the technology transfer process and efforts to increase community participation. Tufte and Mefalopulos (2009) that development communication is a process of disseminating messages to change and increase community participation in the development process (Riva'i, 2016). At the same time, Ade Irma (2013) can provide an overview of the importance of utilizing traditional media because it can give a message of the value of togetherness and is effectively used as a medium that unites every community aspiration in development participation (Irma, 2013). To increase the role of community organizations as 
disseminators of information, the government needs to strengthen the role and capacity of the community media itself. Although traditional media is considered to spend quite a large amount of money, its existence needs to be maintained because it is part of its heritage.

The role of traditional media, which is manifested through folk performances, needs to be clarified. In communication and information, traditional media, which are considered tools, must be optimized for their functions as part of the dissemination of information that is oriented towards development, peace, and national values. The influence of traditional media as a means of social communication is due to the element of homophily. This high level of homophily will affect the way the message is delivered, and the content of the message is flexible to be adapted to local conditions and makes it easier for the public to access the information. As an archipelagic community, the people of the island of Ambon have a communication system as an information dissemination tool developed based on local values and principles.

\section{LITERATURE REVIEW}

According to (Cangara 2002), media is a medium used to convey a message, where this medium is a path or tool with a message running between the communicator and the communicant. Traditional media is known as folk media or, in a narrower sense, folk art. Content and Namezo (in Jahi, 1988) define traditional media as verbal, movement, oral, and visual forms that the people accepted by them widely know, heard, and performed by and for them with the intention of entertaining, informing, explaining, teach and educate. Folk media is a living expression of the lifestyle and culture of a society that has developed over the years. The forms of traditional media are folklore (myths, fairy tales, and legends), expressions (proverbs, proverbs), poetry, singing, theatre, gestures, symbols, sound instruments. Referring to the Regulation of the Minister of Communication and Information Technology Number 08 of 2010 concerning Guidelines for the Development of Empowerment of Social Communication Institutions, Traditional Media are folk performance groups or other similar groups that carry out information dissemination activities and absorption of public aspirations. The use of traditional media as a communication tool has several advantages that should be a concern in the information dissemination process, considering that planning an information campaign that deals with complex issues of society explicitly needs to choose different or appropriate media types to reach different audiences sectors. The suitable communication media are close to the community so that the public can easily understand the messages or information to be conveyed. There are several purposes of using traditional media: building close relationships, binding/gluing social transactions, recognizing/appreciating self-identity and cultural existence, balancing the dominance of modern media, and removing barriers to traditional and modern systems. The themes that usually develop in traditional media involve life, examples, symbols, rituals, cultural ideals, and values (good and bad). In the theme, the desired messages/information is inserted. Through traditional media, all ideas, ideas, and innovations are inserted, told, and adapted to the characteristics of the community to provide social change towards progress. Thus, innovations and local cultural products of the community can complement each other. Traditional media has several distinctive communication functions such as:

1. As a tool used to convey various knowledge and experiences to other members/next generations, such as social experience, knowledge of farming, reading about climate changes, how to protect the environment, and so on;

2. As a means of conveying various moral concepts adopted by the community, which regulates the relationship between them, regulates expected behavior and procedures for rituals that are part of society;

3. As a unifying tool for the community, if one observes, these functions are missing or absent from the various modern media surrounding us today. At the same time, communication is an essential tool in the interaction between individuals in society which is the key to the sustainability of society itself. 
Many previous research results related to the existence of traditional media among rural communities are very effective. Through traditional media, messages tend to be more quickly understood and accepted by the public. In essence, through means born from local wisdom that exists in each region, information dissemination will be easier to do while absorbing various things in the community. In various regions in Indonesia, traditional media appear in various forms and characteristics, in line with the cultural variations that exist in these areas, for example, Tudang Sipulung (Sitting Together), Ma'bulo Sibatang (Gathering Together in a Bamboo Cottage) in Sulawesi South (Chusmeru, 2017).

\section{METHODS OF RESEARCH}

This research uses a qualitative approach with a case study method. Robert K. Yin (2003) defines a case study as an empirical study investigating phenomena in contexts that are not visible and where multiple sources are used. According to Creswell, a case study is a type of qualitative research. Researchers conduct programs, events, processes, activities on one or more people. A case is bound by time and activity, and the researcher collects detailed data using various data collection procedures and continuous time. This research was conducted in this research located in Negeri Hitu Lama, Leihitu District, Central Maluku Regency. Data collection was carried out from August to October. The data collection techniques in this study were direct observation, in-depth interviews, and documentation studies. Data analysis in this study was carried out by analyzing qualitative data from Miles and Huberman (Salim, 2006), which consisted of three stages, namely data reduction, data presentation, and drawing conclusions and verification

\section{RESULTS AND DISCUSSION}

The Kingdom of Tanah Hitu is the Islamic Kingdom located on the island of Ambon, Maluku. This kingdom had a heyday between 1470-1682, with the first king holding the title Upu Latu Titania (King of the question). This kingdom was founded by the Four Primes, who wanted to find out the merits of the good and the absence of a King. The arrival of the Four Primes was the beginning of the arrival of humans in Tanah Hitu as a native of Ambon Island. Four Prime Hitu are also part of the Islamic broadcasters in Maluku. The arrival of the Four Primes is a testament to the history of Islamic syiar in Maluku, which was written by old native and Dutch chroniclers in various versions such as Imam Ridjali, Imam Lamhitu, Imam Kulaba, Holeman, Rumphius, and Valentijn. This kingdom was established before the arrival of western imperialism to the archipelago.

Traditional communication media has advantages that are not owned by modern media because traditional communication is usually exchanged with art and customs, and culture, making this form of communication more attractive, simple, and easy to understand. This makes the traditional communication media applied by the King of Hitu Country in disseminating public information to the community, traditional communication media that are closely attached to people's lives and have an impact on the development of the social process of society so that it can foster a high sense of brotherhood among the community. The social system makes the King a traditional leader and government in Hitu Country. The flow of information from the King will form two streams, namely customary and government information.

Traditional media used to deliver public information in the Old Hitu Country include Saniri, Tifa, and Marino. First, Sansiri, senior, is an essential traditional institution in helping and carrying out their duties. A senior assists King Sansiri Negeri a traditional institution that protects customs and customary law. Sansiri plays a role in assisting the King or Village Head in resolving any disputes within the country or hamlet. Sansiri Negeri consists of a group of people consisting of soa heads, namely the heads of several clans or fam (the term for the family system in Maluku, which is generally based on the father's lineage) which has been determined from generation to generation, Sansiri is also an extension of the information system conveyed by the King to the public, therefore in the dissemination of 
public information carried out in the Land of Hitu Lama is through the representation of each of the SOA Parentah or Sansiri. The two Tifa, Tifa who sounded from the King's residence.

Tifa is a sign that the King asked his people to gather at his residence because he wanted to convey a message/information to all his people. With the sound of Tifa, the community will gather and listen to what will be said. For the people of Hitu, Tifa acts as a traditional communication medium that is used to disseminate information for the people of the country. The third is Marinyo / Tabaous. The existence of Marinyo as a messenger is a characteristic of information dissemination in Hitu Country. It also emphasizes the importance of interpersonal communication within the community of the State. Communication is primarily determined by culture and context. The chosen Marinyo are youth groups in each WIK (complex). Each representative from WIK will choose an individual whose job is to meet with WIK residents and convey various related information. This person is known as Marino.

The people of Hitu Country still use traditional media until this moment. It is just that these media must be preserved for the younger generations in this country. In contrast, the lack of traditional media in delivering public information in Hitu Country is not too influential because the traditional media use has become a routine that is carried out every time conveying information to the public in Hitu Country by the King of Hitu Country.

In communication science, traditional art is also referred to as traditional media, which is often contrasted with mass media or other mainstream media supported by modern communication technology (Nurudin, 2014). One of the communication functions is to fulfill basic human needs such as relational and identity needs, and every communication activity has ethical implications. From the results of these interviews, it can be explained that the use of traditional media has become a pattern in the communication process.

As a traditional leader and government leader in Hitu, the King has been carried out for a long time and is by the social system. The King is a traditional leader and government in Hitu Country so that the delivery of public information has been adjusted to the information to be conveyed. If the information is related to customary information, the media used is through Sansiri. Sansiri can be a representative of each parent or clan that has been appointed. The media used information related to government information is through Marino, sorted from each wiki in Hitu Country.

So that the accessibility of traditional media in the delivery of public information through traditional media in the country of Hitu is still being carried out and maintained by the King, Sansiri, and the Community, folk media/folk performing arts appear in the form of regional arts or traditional regional culture. In traditional communication in rural areas, folk performances as a medium of communication have great potential to reach the masses, mainly because the media has a powerful appeal and is rooted in the community. Traditional media is a communication tool that has long been used in a place (local). With all its advantages, this folk performance media has the potential to be very effective in conveying development communication messages, mainly when it is devoted to regional autonomy

\section{CONCLUSION}

Traditional communication used by the people of the Old Hitu Country in disseminating public information through the representation of the customary council. The use of traditional media in communication in disseminating Public Information in the Hitu Country is carried out by using traditional media to convey information related to the Indigenous government and the State Government itself. Traditional communication has advantages for indigenous people because it builds harmony between the King of Hitu and the people. The accessibility of traditional media in delivering public information through traditional media in Hitu is still being carried out and maintained by the King, such as Sansiri and Tifa.

\section{REFERENCES}

1. Alkhajar, E. N. S. Media Tradisional and Komunikasi Pembangunan. Journal of Rural and Development, 2(2). 
2. Cangara, Hafidz, 2005, Pengantar Ilmu Komunikasi, Jakarta:PT Raja Grafindo Persada.

3. Chusmeru, C. (2017). Pemahaman Mahasiswa Tentang Komunikasi Tradisional. Jurnal Ilmu Komunikasi Acta Diurna, 13(1), 75-88.

4. Effendy, Onong Uchjana, Komunikasi Teori and Praktek, Bandung: Remaja Pengantar Ilmu Komunikasi, Jakarta:Grasindo. Rosdakarya.

5. Karianto, Rachmat, 200 Littlejohn, Stephen W. 2001. Theories of Human Communication. USA: Wadsworth Publishing.

6. Mulyana, Deddy. 2001. Ilmu Komunikasi: Suatu Pengantar. Bandung: Rosda.

7. Irma, A. (2013). Komunikasi Tradisional Efektif Ditinjau dari Aspek Komponen. Jurnal AlBayan: Media Kajian and Pengembangan Ilmu Dakwah, 19(1).

8. Nurdin, M., Nurmaeta, S., \& Tahir, M. (2014). Peran Pemerintah Daerah dalam Pemberdayaan Masyarakat Petani Jagung di Kecamatan Biringbulu Kabupaten Gowa. Otoritas: Jurnal IImu Pemerintahan, 4(1).

9. Riva'i, A. K. (2016). Komunikasi sosial pembangunan: Tinjauan teori komunikasi dalam pembangunan sosial. Hawa and AHWA.

10. Ruben, Brent D, Stewart, Lea P, 2005, Communication and Human Behaviour, USA: Alyn and Bacon.

11. Yin, R. K. (2003). Design and methods. Case study research, 3(9.2). 